\title{
Total lipid content, and lipid and fatty acid composition of the deep-water prawn Pandalus borealis from Balsfjord, northern Norway: growth and feeding relationships
}

\author{
C. C. E. Hopkins ${ }^{1}$, J. R. Sargent ${ }^{2}$, E. M. Nilssen ${ }^{1}$ \\ ${ }^{1}$ Dept of Aquatic Biology, The Norwegian College of Fishery Science, University of Tromse, N-9037 Tromse, Norway \\ ${ }^{2}$ NERC Unit of Aquatic Biochemistry, School of Natural Sciences, University of Stirling, Stirling FK9 4LA, Scotland
}

\begin{abstract}
Variations in total lipid content ( $\mathrm{g}$ of lipid, and as $\%$ of wet and dry body weights) of the prawn Pandalus borealis, ranging from eggs to 52 mo old adults, indicate that lipid growth exhibits marked seasonal oscillations while growth in carapace length shows only comparatively weak seasonality. Positive (anabolic) lipid growth occurs from about April to September inclusive (with up to $40 \%$ of dry body weight as lipid), the major production season for both phytoplankton and herbivorous zooplankton. Negative (catabolic) lipid growth (with lipid being reduced to about $10 \%$ of dry weight) is prominent during the winter. Correspondence analysis involving the relative body-content of total lipid, total protein, ash and water indicates that both 'age' and 'seasonally' related trends are visible; lipid tends to play an increasingly important rôle with age but lipid levels oscillate between peaks in late summer (August/September) and troughs in late winter (February/March). Qualitative investigations of gut contents and analyses of lipid-class composition and fatty acid food-chain markers of selected sizes and ages of prawn indicate that lipid-rich zooplankton (mainly copepods and krill) form the bulk of the food of prawns from 1 to 4 yr old. Although benthic polychaetes and detrital material tend to increase in relative importance with increasing size and age of prawn, they are of secondary importance compared to pelagic organisms. The older prawns frequently contained substantial numbers of capelin scales, probably from feeding on discarded fish from prawn trawling. This study thus reveals that $P$. borealis in north Norwegian fjords is linked trophically to the highly seasonal pelagic production cycle. The lipid percentage of $P$. borealis is, however, less than that of herbivorous zooplankton but substantially greater than that of the lipid-deficient benthos.
\end{abstract}

\section{INTRODUCTION}

The deep-water prawn Pandalus borealis Krøyer is important both commercially and ecologically; despite this, little information exists about its body composition, and thus its nutritional value as a prey species (Shumway et al. 1985, Hopkins et al 1989a). In general, little is known about the body composition of many caridean decapods, and even less is known about the relative energetics of the body components with regard to age or season (Vernberg 1987).

Although growth in Pandalus borealis is often viewed in simple terms as changes in carapace length (CL) per unit time (see Fréchette \& Parsons 1983), recent studies of high-latitude marine organisms have emphasized that 'growth' is a complex blend of factors and body components, which interplay in a dynamic manner with regard to age, season and functional requirements (Hopkins et al. 1985, 1986, 1989b). Lipid, in the absence of significant amounts of carbohydrate (Bảmstedt 1974), is the main energy reserve in P. borealis (Hopkins 1979, Seiring \& Hopkins 1985, Hopkins et al. 1989b). Thus detailed knowledge of the amount, type and seasonal variations of lipid in $P$. borealis is likely to provide important information about the biology and ecology of this species (Sargent \& Whittle 1981, Clarke 1983).

The present paper describes and analyses the growth cycle of lipid in Pandalus borealis from Balsfjord $\left(69^{\circ} \mathrm{N}\right)$, northern Norway. Age-related and sea- 


\title{
Total lipid content, and lipid and fatty acid composition of the deep-water prawn Pandalus borealis from Balsfjord, northern Norway: growth and feeding relationships
}

\author{
C. C. E. Hopkins ${ }^{1}$, J. R. Sargent ${ }^{2}$, E. M. Nilssen ${ }^{1}$ \\ ${ }^{1}$ Dept of Aquatic Biology, The Norwegian College of Fishery Science, University of Tromse, N-9037 Tromsø, Norway \\ ${ }^{2}$ NERC Unit of Aquatic Biochemistry, School of Natural Sciences, University of Stirling, Stirling FK9 4LA, Scotland
}

\begin{abstract}
Variations in total lipid content ( $\mathrm{g}$ of lipid, and as $\%$ of wet and dry body weights) of the prawn Pandalus borealis, ranging from eggs to 52 mo old adults, indicate that lipid growth exhibits marked seasonal oscillations while growth in carapace length shows only comparatively weak seasonality. Positive (anabolic) lipid growth occurs from about April to September inclusive (with up to $40 \%$ of dry body weight as lipid), the major production season for both phytoplankton and herbivorous zooplankton. Negative (catabolic) lipid growth (with lipid being reduced to about $10 \%$ of dry weight) is prominent during the winter Correspondence analysis involving the relative body-content of total lipid, total protein, ash and water indicates that both 'age' and 'seasonally' related trends are visible; lipid tends to play an increasingly important rôle with age but lipid levels oscillate between peaks in late summer (August/September) and troughs in late winter (February/March). Qualitative investigations of gut contents and analyses of lipid-class composition and fatty acid food-chain markers of selected sizes and ages of prawn indicate that lipid-rich zooplankton (mainly copepods and krill) form the bulk of the food of prawns from 1 to $4 \mathrm{yr}$ old. Although benthic polychaetes and detrital material tend to increase in relative importance with increasing size and age of prawn, they are of secondary importance compared to pelagic organisms. The older prawns frequently contained substantial numbers of capelin scales, probably from feeding on discarded fish from prawn trawling. This study thus reveals that $P$. borealis in north Norwegian fjords is linked trophically to the highly seasonal pelagic production cycle. The lipid percentage of $P$. borealis is, however, less than that of herbivorous zooplankton but substantially greater than that of the lipid-deficient benthos.
\end{abstract}

\section{INTRODUCTION}

The deep-water prawn Pandalus borealis Krøyer is important both commercially and ecologically; despite this, little information exists about its body composition, and thus its nutritional value as a prey species (Shumway et al. 1985, Hopkins et al. 1989a). In general, little is known about the body composition of many caridean decapods, and even less is known about the relative energetics of the body components with regard to age or season (Vernberg 1987).

Although growth in Pandalus borealis is often viewed in simple terms as changes in carapace length (CL) per unit time (see Fréchette \& Parsons 1983), recent studies of high-latitude marine organisms have emphasized that 'growth' is a complex blend of factors and body components, which interplay in a dynamic manner with regard to age, season and functional requirements (Hopkins et al. 1985, 1986, 1989b). Lipid, in the absence of significant amounts of carbohydrate (Båmstedt 1974), is the main energy reserve in P. borealis (Hopkins 1979, Seiring \& Hopkins 1985, Hopkins et al. 1989b). Thus detailed knowledge of the amount, type and seasonal variations of lipid in $P$. borealis is likely to provide important information about the biology and ecology of this species (Sargent \& Whittle 1981, Clarke 1983).

The present paper describes and analyses the growth cycle of lipid in Pandalus borealis from Balsfjord $\left(69^{\circ} \mathrm{N}\right)$, northern Norway. Age-related and sea- 
sonal variations in lipid content and lipid class composition are examined with regard to habitat and the seasonal production cycle in the fjord. The fatty acid profile of the prawns' lipid is related to knowledge of their gut contents, the availability of appropriate food, and trophic relationships in a high latitude, fjordic ecosystem (Hopkins et al, 1989a).

\section{MATERIALS AND METHODS}

Sampling. Prawns were trawled from ca $185 \mathrm{~m}$ depth in the Svartnes basin (69.2 $21^{\prime} N, 19^{\circ} 06^{\prime} \mathrm{E}$ ) of Balsfjord, northern Norway (Fig. 1), at about monthly intervals between October 1979 and December 1980. Details regarding trawling procedures and gear are given by Nilssen et al. (1986) and Hopkins \& Nilssen (1990). On deck the contents of the cod end were sorted, and the total volume of the catch of Pandalus borealis was determined. Randomly taken, 2 to 8 I subsamples of $P$. borealis were frozen on board. In addition, ovigerous females were carefully picked out of the catch, and individually frozen to minimize loss of eggs. Egg numbers as a function of female body size were also registered.

Population analyses. In the laboratory ashore, the prawns were thawed at room temperature (ca $21^{\circ} \mathrm{C}$ ), and carapace lengths ( $\mathrm{CL}, \mathrm{mm}$ ) were measured (nearest $0.5 \mathrm{~mm}$ below) by vernier callipers according to the method of Rasmussen (1953).

Year-classes were separated from length-frequency polymodal groups using techniques based on normal distribution theory (see Harding 1949, Cassie 1954), with each modal group representing a single cohort.
Separation of presumptive year-classes/age-groups of prawns and estimation of population parameters (numerical abundance of the respective year-classes, and their mean CL with standard deviation) were carried out using the SYSTAT module NONLIN (Wilkinson 1988a, Hopkins \& Nilssen 1990). These population parameters were later independently corroborated using ELEFAN computer programs (Gayanilo et al. 1988). The presumptive age of prawns within a particular length mode was prescribed using knowledge of the date of sampling, combined with the knowledge that a single cohort is produced annually and that the average date of egg-hatching in Balsfjord is 15 April (Hopkins \& Nilssen 1990). The age-group system (Cushing 1981) is used to describe the year of life of the prawns; 0 -group refers to those in their first year $(<12$ mo old), I-group are those in their second year $(13$ to 24 mo old) and so forth. Length-frequency distributions are shown in Hopkins \& Nilssen (1990) and for reasons of space are not presented here.

Growth in CL was described using the von Bertalanffy growth function (VBGF, von Bertalanffy 1938) modified for seasonal oscillations in growth (Pauly \& Gaschütz 1979):

$$
L_{i}=L_{\infty}\left\{1-\mathrm{e}^{-k \mid\left(t-t_{0}|+|(C / 2 \pi)|\sin | 2 \pi\left(t-t_{s}\right) \mid\right.}\right\}
$$

where $L_{\infty}=$ asymptotic $\mathrm{CL}_{i} K=$ growth constant; $C=$ constant expressing the amplitude of growth oscillation; $t_{\mathrm{s}}=$ starting point of oscillation with respect to $t=$ $0_{i} t_{0}=$ origin of the growth curve $;$ and $L_{t}=$ length at age $t$. This equation reduces to the classic VBGF when $C=$ 0 (i.e. no seasonal oscillation). The parameter $t_{\mathrm{s}}$ is defined such that $t_{\mathrm{s}}+0.5=$ the 'winter' point (WP), i.e. the turning point in time when growth accelerates after the seasonal stagnation (Pauly 1984). The parameters were estimated using the SYSTAT module NONLIN (Wilkinson 1988a); verification was conducted by the ELEFAN programs (Gayanilo et al. 1988). Specific growth rates (SG) for CL were calculated as:

$$
\mathrm{SG}(\%)=\ln \left(L_{2}-L_{1}\right) /\left(t_{2}-t_{1}\right) \times 100
$$

where $L_{2}$ and $L_{1}$ are the lengths at the end and the beginning of the period delineated by times $t_{2}$ and $t_{1}$ respectively. SG is particularly useful for discerning changes in growth trends and periodicity with age and season (Hopkins et al. 1984b). 
Analyses of body components. Between 7 and 20 undamaged prawns were chosen from each of the modal CL groups representing the various age-groups present on each of the sampling dates. Wet weights (WW) and dry weights (DW, after drying for $48 \mathrm{~h}$ at $60^{\circ} \mathrm{C}$ ) were determined to the nearest $0.2 \mathrm{mg}$ for individual prawns. WW of ovigerous females was taken with and without their egg masses, and DW was then taken separately for females and their egg masses. Individual specimens (prawns/egg masses) were finely crushed with pestle and mortar, and the homogenized material placed in labelled vials and stored in a desiccator with self-indicating silica gel. Samples of this material were analyzed for ash (after incineration at $550^{\circ} \mathrm{C}$ ), carbon and nitrogen (Carlo Erba model 1104 Elemental Analyser, with azobenzol as the standard), total lipid (Folch et al. 1957), protein (Gornall et al. 1949, following recommendations of Hopkins et al. 1984a) and energy content (kilojoule, $\mathrm{kJ}_{\text {i }}$ Phillipson 1964). In the present paper only data involving WW, DW, water content, and total lipid, total protein and ash are treated.

Lipid class and fatty acid composition. Lipids, after being dissolved in chloroform/methanol (2:1 by vol.) to give a concentration of ca $10 \mathrm{mg} \mathrm{ml}^{-1}$, were subjected to thin layer chromatography on layers of silicic acid $(250 \mu \mathrm{m})$ using hexane : diethyl ether : acetic acid $(90$ : $10: 1$ by vol.) as developing solvent. Individual lipid classes were measured by quantitative densitometry by methods detailed earlier (Fewster et al. 1969, Sargent \& Falk-Petersen 1981). Fatty acid methyl esters were prepared from individual lipids by transmethylation in methanol-sulphuric acid after separating total lipids by thin-layer chromatography. Isolated wax esters were saponified and fatty alcohols converted to their acetate derivatives with acetic anhydride in pyridine (Farquhar 1962). Analyses of fatty acid methyl esters and fatty alcohol acetates were performed using a Packard 429 gas chromatogram equipped with a fused silica capillary column coated with the liquid phase CP Wax 51 as detailed by Sargent \& Falk-Petersen (1981).

Data base and statistical analyses. Data for WW, DW, water content, total lipid, total protein and ash for individual prawns/egg masses were registered by agegroups (eggs arbitrarily designated as 1 mo old) in the EDIT module (data editor) of SYSTAT (Wilkinson 1988a).

Percentages have a variance dependent upon the expected proportion; this problem was eliminated by using an arcsine transformation (Zar 1974), where $p$ is an observed percentage:

$$
Y=\arcsin , \overline{(p)}
$$

and the transformed percentage (\%) value is calculated:

$$
\%=[(Y \times 57.296) / 90]
$$

Descriptive statistics for the 23 age-groups were calculated using the STATS module of SYSTAT (Wilkinson 1988a).

Lipid weight-length regressions were fitted using the linearized form of the power-curve expression (Ricker 1975):

$$
\ln W=\ln \alpha+\beta(\ln L)
$$

where $W=$ weight of total lipid $(g)$ of the prawn; $L=$ carapace length $(\mathrm{mm})$; and $\alpha$ and $\beta$ are the regression constant and regression coefficient respectively. Regression analyses were performed using the MGLH module of SYSTAT (Wilkinson 1988a). An analysis of covariance (ANCOVA) was performed with the same module on the regressions to test whether there was significant monthly heterogeneity.

Correspondence analysis (CA) was carried out on the major body components spanning from eggs to 52 mo old adult females. CA, also known as 'Reciprocal Averaging', is a useful statistical technique for scaling, and also for providing a basis for automatic classification (Hill 1982). CA has previously demonstrated its usefulness in examining 'condition' changes in zooplankton and fish in an age/season context (Hopkins et al. 1985, 1986). In the present study, CA has been used as a technique for mapping months (prawn age/calendar month) in a Cartesian diagram so that the distance between any 2 months reflects dissimilarity between the corresponding line-profiles. The body-component data are also plotted in the same diagrams so that dissimilarity between column profiles is reflected in ordinary distances between the plotted points. It is also possible to interpret the months in terms of the body components and vice versa. If a month is plotted in the direction of a given body component this means that the latter is over-represented that month. In this way it is possible to examine relationships between months (and thereby also age), and between months and body constituents. An exploration of the basic interdependence between the various compositional components, and their relationship in an age/month framework, is also likely to provide a better understanding of the term 'growth'.

CA was performed, using the NTSYS-pc programme CORRESP (Rohlf 1989), with the following 5 body components: total lipid, total protein, ash, water, and 'rest'. Frequencies relative to wet body weight (WW) were used. 'Rest' was estimated by subtracting the other variables from unity; it can be assumed to be primarily carbohydrate (see Bamstedt 1974).

Trend analysis has been used when desired to avoid semi-subjective regression techniques, to fit a curve 
illustrating a basic pattern in the data. This has been achieved by using 'locally weighted scatterplot smooth' methods (Cleveland 1979) implemented in SYSTAT and SYGRAPH (Wilkinson 1988a, b).

\section{RESULTS}

\section{Growth in CL}

Growth in CL of the Balsfjord Pandalus borealis studied here is described by the seasonally oscillating VBGF (Fig. 2) with the following parameters:

$$
L_{\infty}=26.9, K=0.37, C=0.40, t_{s}=0.42 \text {, }
$$

with $t_{0}$ being adjusted to -0.10 . Stagnation in CL growth is visible during the winter months, with the 'winter point' (WP) occurring in March/April. The WP is clearly discerned in the specific growth rate (SG) plot (Fig. 2) as the recurrent 'troughs' separating the stagnatory (winter: October to March) from the reinvigorated (spring/summer: April to September) growth periods.

\section{Changes in body weight and lipid content with $C L$ and age}

Variations in total lipid, lipid as \%WW, and lipid as $\% \mathrm{DW}$, as a function of $\mathrm{CL}$ are shown in Fig. $3 \mathrm{~A}$ to $\mathrm{C}$, while variations in the same 3 variables as a function of age (in mo) are shown in Fig. 3D to F. Between 10 mo (about $8 \mathrm{~mm} \mathrm{CL}$ ) and $52 \mathrm{mo}$ of age (about $21 \mathrm{~mm} \mathrm{CL}$ ) total lipid per individual increased from ca 0.06 to $1.4 \mathrm{~g}$ (Fig. 3A, D). Percentage lipid content, over the same age and size spans, varied from ca 1 to $11 \%$ of WW (Fig. 3B, E) and ca 10 to $40 \%$ of DW (Fig. 3C, F). Although the progression from 10 to 52 mo is characterised by various oscillations for both absolute ( $g$ ind. ${ }^{-1}$ ) as well as proportionate (\%) levels of total lipid, the latter periodicity is the clearer of the two. For example, from 10 to 19 mo of age young prawns steadily increased the percentage of total lipid in their bodies from 10 to $40 \% \mathrm{DW}$, before proceeding through a series of alternating troughs and peaks varying between ca 12 and $40 \%$ DW. Major peaks appeared at approximately annual intervals (Fig. 3E, F) in late summer/autumn.

The externally borne egg mass of ovigerous females (spawned in September and carried under the female until hatching in April) showed great variation in its percentage lipid content (Fig. 3B, C, E, F) i eggs sampled in February (ca 5 mo after spawning), March, and April ('eyed' eggs about 7 mo after spawning and just before hatching) had mean values, as \%DW, of 17.8 , 24.7 and $22.7 \%$ respectively. The eggs removed from adult females in December were still developmentally dormant, allowing these to be used to provide an estimate of reproductive output ( $\mathrm{RO}$, weight of eggs to weight of maternal female) for WW, DW and total lipid weight (LW) of 13.1, 8.7, and 10.5\% respectively.

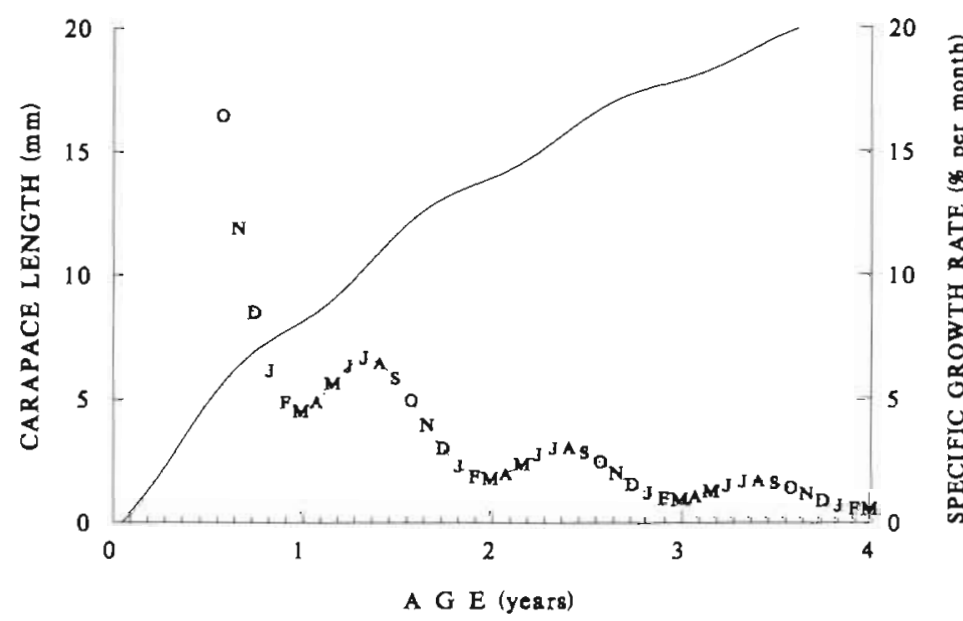

Fig. 2. Pandalus borealis. Seasonally oscillating von Bertalanffy growth function (VBGF) for carapace length ( $\mathrm{CL}, \mathrm{mm}$ ) as a function of age, and corresponding specific growth rates for the population from the Svartnes basin of Balsfjord, northern Norway. 'Winter points' reflecting the change from periodic stagnatory growth to reinvigorated growth correspond with the 'troughs' (seen around March) in specific growth rate. Letters in the specific growth rate plot refer to progression of calendar months

\section{Lipid weight-length regressions}

The regression equations (power-curve function) describing the relationship between individual total lipid content (i.e. g lipid per animal) and CL from sampling in February, March, April, June, August, October and December are presented in Table 1. All regressions are highly significant $(p<0.001)$. The regression coefficients (i.e. slope, $\beta$ ) varied from 1.60 to 4.37 , and exhibited a high degree of monthly heterogeneity (ANCOVA: $F_{6.206}=27.6, \mathrm{p}<0.001$ ). Thus, a single 'combined' regression fit for all months could not be justified.

\section{Lipid class and fatty acid composition}

In Balsfjord Pandalus borealis triacylglycerols (TAG) account for the major fraction of neutral lipids (Fig. 4); wax esters only 

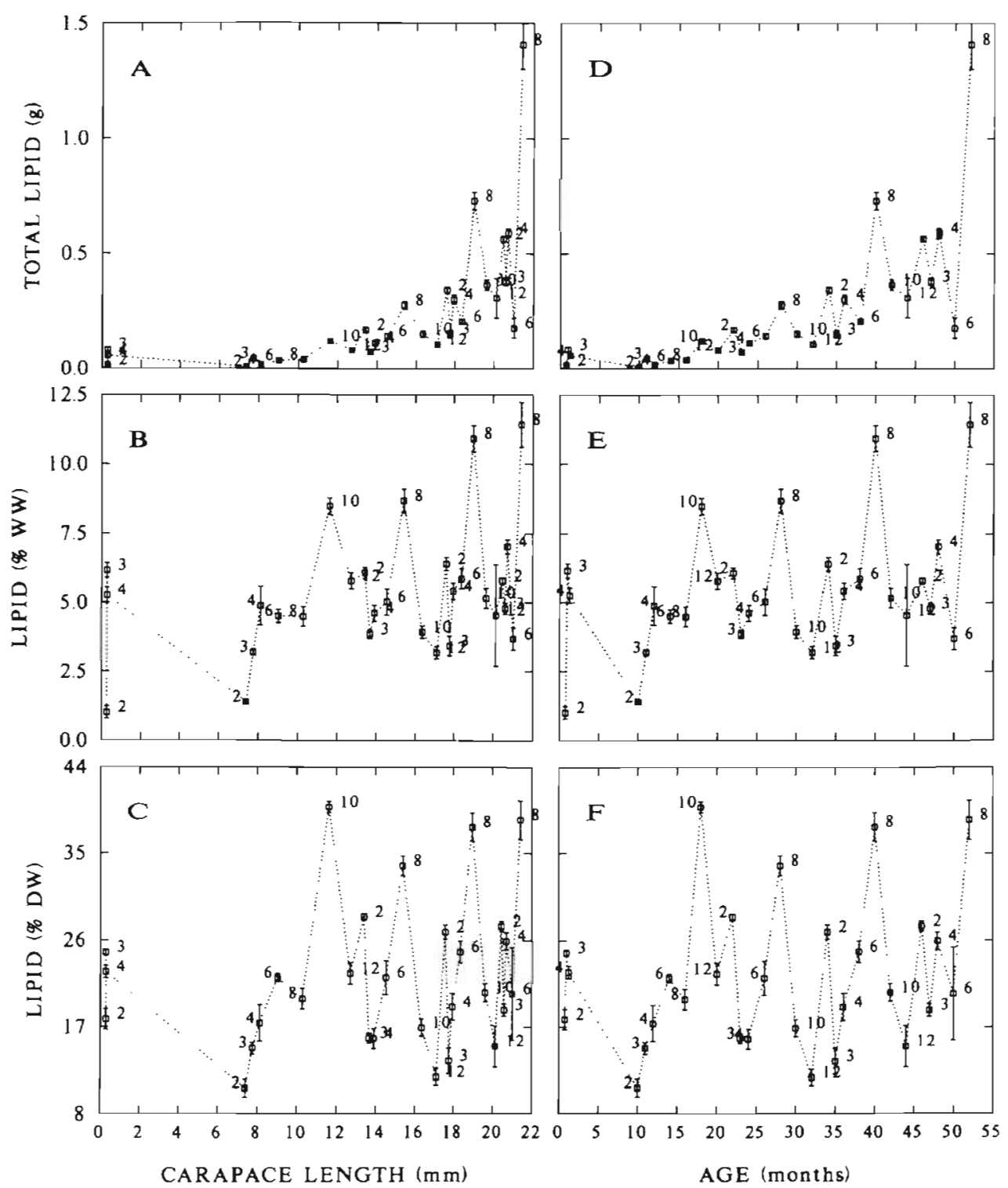

Fig. 3. Pandalus borealis. Carapace length ( $A$ to $C$ ) and age (D to F) related changes in total lipid ( $g$ ), percentage lipid as $\%$ wet weight (WW) and \% dry weight (DW). Values given as means with 1 standard error. Eggs are indicated close to carapace and age points 0 . Numbers given by the data points refer to calendar months (1: January; 12: December)

Table 1. Pandalus borealis, Balsfjord. Power-curve regressions of type $\ln L W=\ln \alpha+\beta(\ln C L)$. $L W$ : weight (g) of total lipid in body (includes roe in ovigerous females); $C L$ : carapace length $(\mathrm{mm}) ; \alpha$ : regression constant; $\beta$ : regression coefficient; SE $\beta$ : standard error of $\beta ; n$ : number of individuals; $r^{2}$ : adjusted coefficient of determination. $F=$ Fisher value, null hypothesis $\left(\mathrm{H}_{0}\right)=\beta=0$, i.e. variation in $W$ cannot be explained by the regression. $\cdots p<0.001$

\begin{tabular}{|c|c|c|c|c|c|c|c|}
\hline Month & $\mathrm{n}$ & $\beta$ & $\mathrm{SE} \beta$ & $\ln \alpha$ & $r^{2}$ & $F$ & $\mathrm{p}$ \\
\hline Feb & 35 & 4.372 & 0.122 & -13.897 & 0.974 & 1284.0 & $\cdots$ \\
\hline Mar & 36 & 2.591 & 0.168 & -9.240 & 0.871 & 237.4 & $\cdots$ \\
\hline Apr & 37 & 3.564 & 0.162 & -11.904 & 0.931 & 486.1 & $\cdots$ \\
\hline Jun & 30 & 2.528 & 0.218 & -9.090 & 0.821 & 123.4 & $\cdots$ \\
\hline Aug & 30 & 4.422 & 0.124 & -13.851 & 0.978 & 1276.7 & $\cdots$ \\
\hline Oct & 30 & 2.306 & 0.284 & -8.184 & 0.692 & 66.1 & $\cdots$ \\
\hline Dec & 22 & 1.603 & 0.359 & -6.746 & 0.474 & 19.9 & $\cdots$ \\
\hline
\end{tabular}




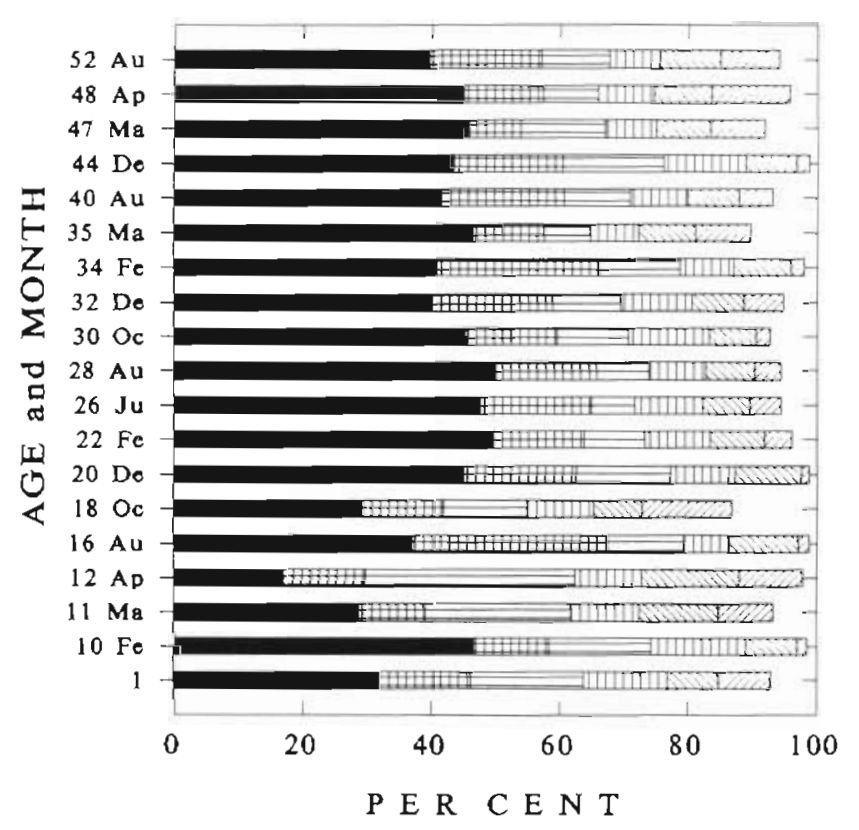

Fig. 4. Pandalus borealis. Age (in months, denoted by numbers) and calendar months (denoted by first 2 letters of month) related changes in lipid class composition (HC: hydrocarbons; ST: sterols; PAG: partial acylglycerol; PHLIP: phospholipids; FFA: free fatty acids; TAG: triacylglycerol). Age 1: eggs carried by berried females

HC
ST
DAG
P PHLIP
AFA
TAG

occurred in trace amounts. TAG increased from ca $20 \%$ of the total lipid at about 12 mo of age, reaching a maximum of ca $50 \%$ at about 24 mo; thereafter only relatively small oscillations occur.

Fatty acid analysis of the triacylglycerols shows an essentially constant fatty acid profile as the animal grows, with some notable exceptions. $16: 0$ is the major saturate with $16: 1(n-7)$ and $18: 1(n-9)$ being the major monounsaturates (Table 2). It is of interest that $20: 1(n-9), 22: 1(n-9)$ and $22: 1(n-11)$ are present in moderate amounts in triacylglycerols, the highest percentage of these fatty acids being found in younger animals. The decreased percentages of 20:1 and 22:1 in triacylglycerols in the more mature prawns are accompanied by increased percentages of both the $(n-9)$ and $(n-7)$ isomers of 18:1. Small amounts $(<5 \%$ of total lipid) of wax esters rich in $20: 1$ and 22:1 fatty alcohols are also present in the total lipid (Table 3).

\section{Stomach contents}

The stomachs of prawns of different age-groups were opened during spring and summer, and qualitative registration of the contents carried out (Table 4 ). Younger prawns (0-and I-group) primarily contained

Table 2. Pandalus borealis, BaIsfjord. Fatty acid analyses of lipids, sampled in April. I, TI \& IV refer to age-groups of prawn, which are accordingly 12,24 and 48 mo old respectively. Eggs are those removed from maternal IV-group females. Data are expressed as wt \%. Lipid classes were isolated and derivatives prepared for GLC analyses as detailed in 'Materials and methods' $-:<0.5 \%$

\begin{tabular}{|c|c|c|c|c|c|c|c|c|}
\hline \multirow[t]{2}{*}{ Constıtuent } & \multicolumn{4}{|c|}{ Phospholipid } & \multicolumn{4}{|c|}{ Triacylglycerol } \\
\hline & I & II & IV & Eggs & I & II & IV & Eggs \\
\hline $14: 0$ & 4.1 & 2.7 & 2.4 & 2.9 & 3.7 & 4.4 & 4.1 & 3.6 \\
\hline Iso $15: 0$ & - & - & - & - & 0.5 & - & - & - \\
\hline $15: 0$ & 0.8 & - & - & - & 0.7 & - & - & 0.6 \\
\hline $16: 0$ & 27.9 & 24.1 & 20.1 & 24.8 & 21.4 & 19.5 & 1.8 .3 & 21.3 \\
\hline $16: 1(n-9)$ & - & - & - & - & 0.7 & - & - & - \\
\hline $16: 1(n-7)$ & 7.4 & 5.4 & 5.8 & 8.8 & 11.4 & 11.9 & 11.4 & 13.2 \\
\hline Iso $17: 0$ & - & - & - & - & 0.8 & 0.6 & 0.6 & 0.5 \\
\hline Ant iso $17: 0$ & - & - & - & - & 0.7 & 0.5 & - & - \\
\hline $17: 0$ & 1.3 & 0.8 & 1.0 & 0.7 & 1.5 & 1.5 & 1.2 & 1.0 \\
\hline $18: 0$ & 4.4 & 3.1 & 3.6 & 2.5 & 3.9 & 3.0 & 3.1 & 1.9 \\
\hline $18: 1(n-9)$ & 15.0 & 19.4 & 20.3 & 20.8 & 22.8 & 26.4 & 26.0 & 27.9 \\
\hline $18: 1(n-7)$ & 9.7 & 11.4 & 9.9 & 12.1 & 6.6 & 8.3 & 8.5 & 8.9 \\
\hline $18: 1(n-5)$ & - & - & - & 0.5 & 0.6 & 0.6 & 0.6 & 0.5 \\
\hline $18: 2(n-6)$ & - & - & 1.4 & 1.3 & - & 1.2 & 1.3 & 1.4 \\
\hline $18: 3(n-3)$ & - & - & - & - & - & 0.5 & 0.6 & 0.5 \\
\hline $18: 4(n-3)$ & - & - & - & - & - & 0.6 & 0.8 & 0.7 \\
\hline $20: 1(n-9)$ & 4.0 & 1.8 & 0.7 & 0.9 & 6.0 & 3.3 & 3.5 & 2.0 \\
\hline $20: 1(n-7)$ & 1.7 & - & 1.7 & 0.4 & 2.0 & 1.3 & 1.3 & 0.8 \\
\hline $20: 4(n-6)$ & 0.8 & - & 1.0 & 0.9 & - & - & 0.8 & 0.6 \\
\hline $20: 5(n-3)$ & 4.2 & 13.7 & 11.2 & 11.3 & 0.7 & 3.7 & 4.3 & 5.7 \\
\hline $22: 1(n-11)$ & 2.6 & - & 1.3 & - & 9.1 & 2.1 & 2.5 & 1.3 \\
\hline $22: 1(n-9)$ & - & - & 0.5 & - & 1.0 & 0.5 & 0.5 & - \\
\hline $22: 6(n-3)$ & 2.5 & 7.8 & 6.6 & 4.8 & - & 2.2 & 3.1 & 2.0 \\
\hline Other $22-24$ & 2.2 & 1.7 & 2.5 & 0.9 & - & - & - & - \\
\hline
\end{tabular}


Table 3. Pandalus borealis, Balsfjord. Analyses of wax ester fatty alcohols of lipids, sampled in April. I, II \& IV refer to agegroups of prawn, which are accordingly 12,24 and 48 mo old respectively. Eggs are those removed from maternal IV-group females. Data are expressed as wt \%. Lipid classes were isolated and derivatives prepared for GLC analyses as detailed in 'Materials and methods'

\begin{tabular}{|lrrrr|}
\hline Constituent & \multicolumn{1}{c}{ I } & II & IV & Eggs \\
\hline $14: 0$ & 3.4 & 1.7 & 3.0 & 4.0 \\
$16: 0$ & 11.8 & 26.2 & 20.2 & 14.2 \\
$16: 1$ & 1.7 & 1.5 & 2.7 & 3.5 \\
$18: 0$ & 13.3 & 10.0 & 7.7 & 9.8 \\
$18: 1$ & 6.7 & 7.4 & 5.4 & 6.1 \\
$20: 0$ & 8.2 & 4.4 & 3.0 & 5.7 \\
$20: 1$ & 9.9 & 8.3 & 6.6 & 8.9 \\
$22: 0$ & 3.7 & 5.5 & 2.3 & 3.5 \\
$22: 1$ & 11.1 & 10.2 & 16.2 & 8.0 \\
Total & 69.8 & 75.2 & 67.1 & 63.7 \\
\hline
\end{tabular}

Table 4. Pandalus borealis, Balsfjord. Qualitative registration of degree of occurrence (-: absent; + : frequent, but not dominant; ": frequent, dominant) of prey/material in stomach contents of 0 - to IV-group prawns during spring and summer

\begin{tabular}{|lccccc|}
\hline Stomach contents & \multicolumn{5}{c|}{ Age-group } \\
& 0 & I & II & IIl & IV \\
\hline Calanoid copepods & $\cdot$ & $\cdot$ & $\cdot$ & + & + \\
Euphausiids & - & + & + & $\cdot$ & $\cdot$ \\
Capelin scales & - & - & + & $\cdot$ & $\cdot$ \\
Polychaetes & - & - & + & + & + \\
Mineral particles & - & - & + & + & + \\
\hline
\end{tabular}

Table 5. Pandalus borealis, Balsfjord. (A) Percentage of the various body components distributed along the first 3 axes, and (B) percentage contribution from the various body components to the first 3 axes, of the correspondence analysis plot in Fig. 5

\begin{tabular}{|c|c|c|c|c|}
\hline $\begin{array}{l}\text { (A) } \\
\text { Component }\end{array}$ & $\begin{array}{l}\text { Axis I } \\
(39.4)\end{array}$ & $\begin{array}{c}\text { Axis II } \\
(31.8)\end{array}$ & $\begin{array}{c}\text { Axis III } \\
(25.4)\end{array}$ & $\begin{array}{l}\text { Sum } \\
(\%)\end{array}$ \\
\hline Lipid & 27.5 & 25.4 & 46.8 & 99.7 \\
\hline Protein & 8.0 & 67.7 & 23.2 & 98.9 \\
\hline Ash & 16.3 & 27.5 & 8.3 & 52.1 \\
\hline Water & 50.1 & 44.5 & 5.4 & 100.0 \\
\hline Rest & 77.4 & 5.2 & 17.0 & 99.6 \\
\hline \multicolumn{5}{|l|}{ (B) } \\
\hline Component & $\begin{array}{l}\text { Axis I } \\
(39.4)\end{array}$ & & $\begin{array}{l}\text { Axis II } \\
(31.8)\end{array}$ & $\begin{array}{c}\text { Axis lil } \\
(25.4)\end{array}$ \\
\hline Lipid & 19.3 & & 22.1 & 51.1 \\
\hline Protein & 5.3 & & 55.7 & 23.9 \\
\hline Ash & 2.6 & & 5.4 & 2.1 \\
\hline Water & 0.5 & & 11.5 & 1.8 \\
\hline Rest & 62.3 & & 5.2 & 21.2 \\
\hline Sum & $100 \%$ & & $100 \%$ & $100 \%$ \\
\hline
\end{tabular}

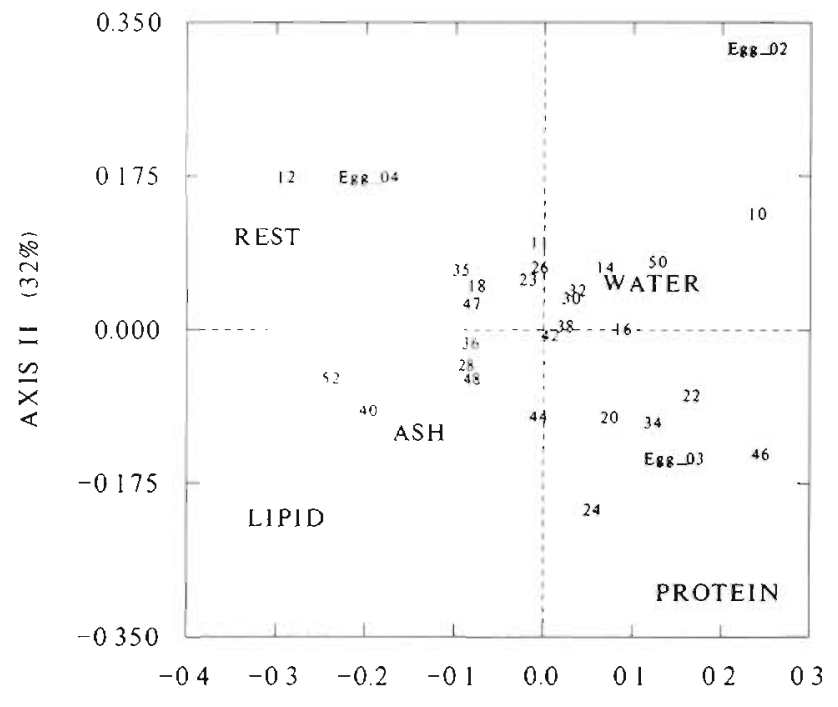

AXIS I (39\%)

Fig. 5. Pandalus borealis. Correspondence analysis plot of Axis I and Axis II, relating body components (total lipid, total protein, water, ash and 'rest') and age (e.g. 10:10 mo old, February; 12: 12 mo old, April; Egg_02, Egg_03, Egg_04: eggs removed from ovigerous females in February, March, and April respectively) of prawns/eggs

identifiable remains of calanoid copepods (chiefly Calanus finmarchicus, Metridia longa and Pseudocalanus spp.) and little 'mineral' material (i e. sand/ mud particles). On the other hand, older prawns (IIand III/IV-groups) primarily contained identifiable remains of krill (euphausiids, Thysanoessa spp.; sometimes 'chewed' but whole specimens, often undigested photophores and omatidia from the eyes). The oldest prawns (III- and IV-groups), in addition to containing copepods and krill, also frequently contained minute fish-scales (of capelin Mallotus villosus) and occasional remains of polychaetes.

\section{Relationship between body components and season}

A CA plot for the first 2 axes (Axes I and II) for body components (total lipid, total protein, ash, water and 'rest') of Balsfjord Pandalus borealis is shown in Fig. 5. The first 2 axes accounted for a high proportion $(71.2 \%)$ of the total variation present (Table 5). The percentage of the various body components distributed along the first 3 axes of the $C A$ is given in Table 5A, while the percentage contribution by the various body components to the first 3 axes is given in Table 5B.

The inherent relationships between the various body components and between components and months 
can be discerned from their position in the 2dimensional data space of Fig. 5. Total lipid and 'rest' are juxtaposed with total protein and water along Axis I, while total lipid and total protein are juxtaposed with water and 'rest' along Axis II. This clearly illustrates that an increase in total lipid is associated with a decrease in water, and to a lesser extent total protein along Axis I, while an increase in total protein, and to a lesser extent total lipid, is associated with a decrease in water. Although 'rest' provides a relatively large contribution to Axis I (Table 5B), its diminutive contribution to the body composition of Pandalus borealis (Båmstedt 1974) argues that relatively little emphasis
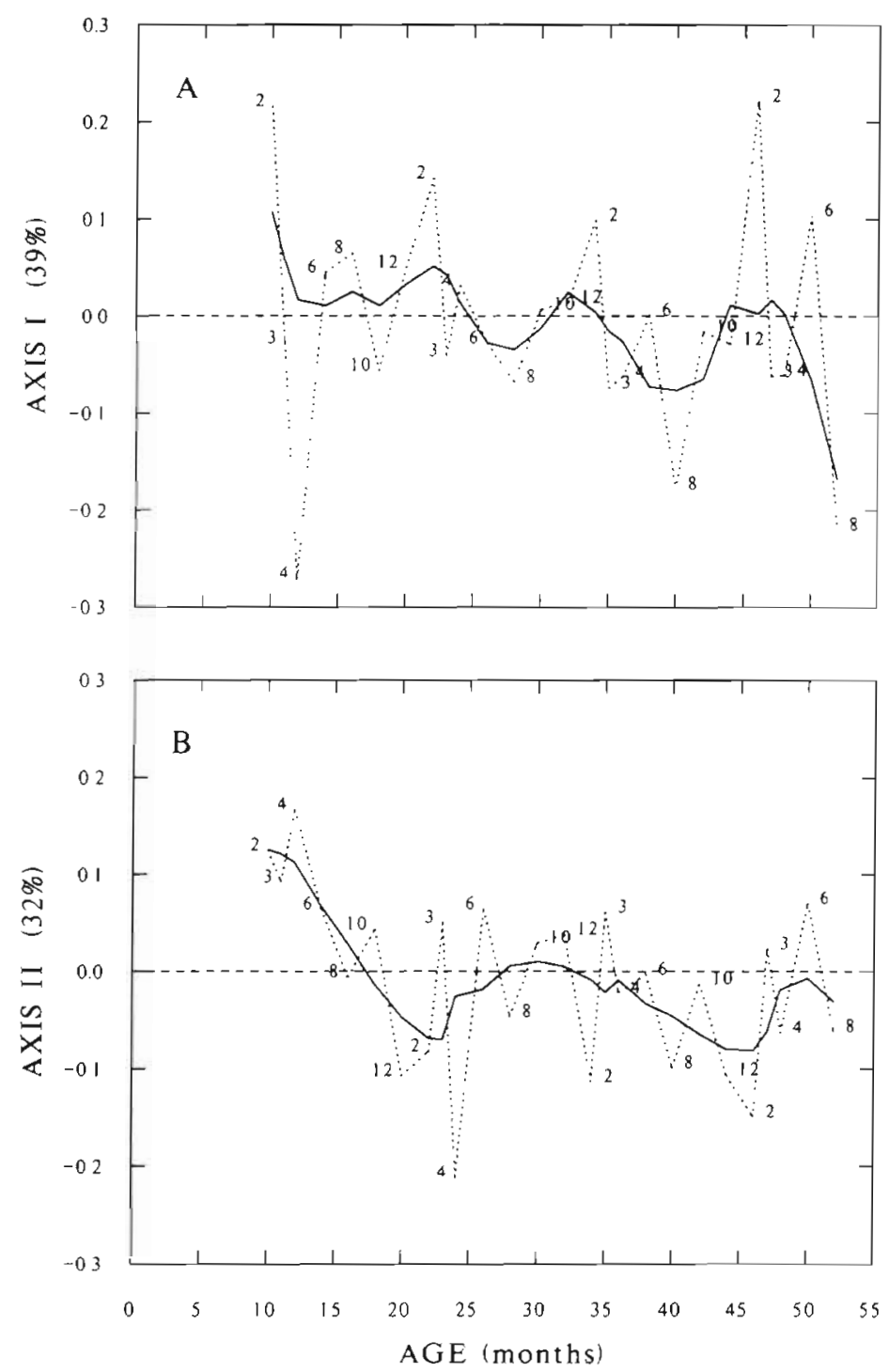

Fig. 6. Pandalus borealis. Plot of factor scores from the correspondence analysis for (A) Axis I and (B) Axis II as a function of prawn age. Dotted line connects progression of data points, where numbers indicate calendar months (e.g. 4: April; 8: August). Solid line: fitted Cleveland smoother trend (see 'Materials and methods') need be placed on its influence in an energetics or growth/condition context. Ash plays a minor role in the total variation along the 2 axes, and is only a small fraction of the WW of $P$. borealis. Examples of prawns characterised by having a high proportion of lipid and thus a relatively low proportion of protein and water are those of 40 and 52 mo of age. Examples of prawns characterised by having a high proportion of water and protein and thus a relatively low proportion of lipid are those of 10 and 46 mo of age (Fig. 5).

A plot of the factor scores of Axis I against increasing age indicates that a cyclical pattern is present; the underlying trend is enhanced with the fitting of the Cleveland smoother (Fig. 6A). 'Troughs' (associated with negative scores, and thus positively associated with strong lipid influence; see Table 5 and Fig. 5) occur about August (i.e. Month 8, towards the end of the summer), while 'peaks' (associated with positive scores, and thus positively associated with water, and to a lesser degree protein influences) occur about February (i.e. Month 2, towards the end of the winter). It is evident that ages 40 and 52 (both Month 8, i.e. August) are particularly lipid-influenced, corroborating the point recently made regarding their position in Fig. 5. Superimposed on this seasonal trend is a trend for increasingly negative factor scores with increasing age, indicative of the increasing influence of lipid.

A plot of the factor scores of Axis II against increasing age (Fig. $6 \mathrm{~B}$ ) is not so informative as that for Axis I. The otherwise evident annual periodicity seen in Fig. 6A is no longer present, but the steady increase in relative ( $\% \mathrm{WW}$ and $\%$ DW ) amounts of total lipid seen in Fig. 3 occurring from about 12 to 24 mo of age are reflected in Fig. 6B.

\section{DISCUSSION}

\section{Growth and lipid}

The Balsfjord Pandalus borealis analysed here had a growth curve in carapace length which exhibited relatively weak seasonal oscillations. The winter point (marking the time at which renewed CL growth starts) occurred in March, the month in which phytoplankton production commences in Balsfjord (Eilertsen \& Taasen 1984). There are basic similarities, but also appreciable differences in the seasonal $\mathrm{CL}$ growth of $P$. borealis and krill (Thysanoessa spp.) in Balsfjord. Although both P. borealis and 
the mainly herbivorous Thysanoessa spp. exhibit seasonal oscillations, the oscillations of the latter are much more pronounced, both in terms of CL and of lipid variation (see Hopkins et al. 1984b).

Despite exhibiting weak seasonal oscillations in length-at-age (which are more clearly emphasised as specific growth rate presentations), Balsfjord Pandalus borealis undergo marked variations in their lipid content in terms of \%DW, reaching up to $40 \%$ towards the end of the summer/early autumn before declining to about $10 \%$ during the winter. Such variation is, however, relatively moderate compared with those seen in the obligate herbivore Thysanoessa inermis (where up to ca $60 \%$ of DW may be total lipid; Falk-Petersen 1981). Although a high proportion of the phytoplankton production is classically considered to directly sediment to the bottom at high latitudes (Cushing 1975), little recognizable particulate organic material has been detected arriving at the bottom in Balsfjord, and most of this is principally in the form of faecal pellets (Lutter et al. 1989). Clearly discernible changes in the qualitative composition of the surface bottom-sediments are not evident (Sargent et al. 1983)

Correspondence analysis performed on relative body composition (involving total lipid, total protein, ash, and water) of Pandalus borealis clearly demonstrated that most of the variability could be explained by the first 2 axes, in terms of biology, through changes in total lipid, total protein and water. The factor scores from the first axis, along which total lipid and water were juxtaposed, when plotted against age clearly showed seasonal cycles peaking in terms of lipid about August (towards the end of the production season) and declining to a minimum about February/March (at the end of the winter). This situation depicts the inverse relationship between lipid and water in aquatic animals (Love 1970, Sargent 1976). Thus the age-groups clustering towards the 'lipid end' of the plot represent anabolic periods (i.e. summer, when food consumption provides energy in excess of total metabolism; see Clarke 1987), while the reverse represents catabolic periods (i.e. a drain in the energy budget). The importance of lipid as the major energy reserve in $P$. borealis increases with age (Seiring \& Hopkins 1985); this is also reflected in the trend of increasing lipidaffinity seen in the factor-score plot for Axis I (Fig. 6A). However, in larval $P$. borealis low neutral lipid (measured as poor triacylglycerol condition) reserves are closely correlated with higher mortalities during the early moult periods (Ouellet et al. 1992), thus suggesting that inferior lipid condition in the relatively lipid-deficient younger stages may pose the critical mortality risk.

\section{Compositional characteristics of lipid and feeding}

It is generally accepted that high levels of body lipid, and a larger reliance on wax esters rather than on triacylglycerols, are characteristic features of marine pelagic crustaceans living in environments where shorter periods of food plenty are followed by longer periods of food scarcity (Lee \& Hirota 1973, Lee 1975, Sargent \& Whittle 1981). This has shown to be especially applicable to 'deep-water' species, and those living at high latitudes, e.g. in the arctic (Clarke 1983, Sargent \& Henderson 1986). Obligate herbivores, of necessity having to overwinter without feeding, are especially characterised by having very high proportions of their dry body weight as neutral, reserve lipid, of which nearly all is wax ester. This is well illustrated in the case of Balsfjord krill where Thysanoessa inermis (an obligate herbivore) has up to $60 \%$ of its DW as lipid with the majority being wax ester, while Meganyctiphanes norvegica (a more opportunistic species, with a highly carnivorous diet) has less than half the percentage lipid content of $T$. inermis, and is rich in triacylglycerol but does not contain wax esters (Falk-Petersen et al. 1981). The present findings for Balsfjord Pandalus borealis, with only 10 to $40 \%$ of their DW as lipid, primarily comprised of triacylglycerol, are similar to those previously recorded for this species (Ackman \& Eaton 1967). Balsfjord P. borealis are, in terms of their lipid content and lipid class composition, more typically classifiable as omnivorous/carnivorous, rather than being immediately related to the primary production cycle.

Compared with other boreal/polar caridean and hypolitid prawns (e.g. Pandalus montagui, Clarke 1979; Chorismus antarcticus, Clarke 1977a, b, 1982), Balsfjord $P$. borealis exhibit not only greater peak levels of lipid on a percentage-weight basis but also exhibit more marked seasonal variations between peaks and troughs. Periods of lipid anabolism (i.e. increasing lipid content) occur in spring and summer, while periods of lipid catabolism occur in the winter. Despite not being herbivorous, Balsfjord $P$. borealis are apparently linked to the periodicity of the pelagic production cycle. Although Clarke (1983) proposes that the breeding cycle appears to be the major influence on lipid storage and utilization in benthic invertebrates, the marked cyclical changes in lipid in younger $P$. borealis demonstrate the importance of seasonal factors unrelated to maturation. A difference in tissue energy concentration and lipid content between benthos and plankton has been emphasised (Norrbin \& Bămstedt 1984, Clarke \& Peck 1991): the present data (lipid generally varying from 10 to $40 \%$ of dry body weight) for $P$. borealis, although not lipid-rich enough to classify it with the herbivorous zooplankton, clearly 
indicate its lack of affinity with the lipid-deficient benthos.

Although Pandalus borealis is frequently described as being a predominantly benthic feeder (see Shumway et al. 1985), the qualitative registration of stomach contents indicates that the major dietary input of Balsfjord $P$. borealis is pelagic zooplankton (calanoid copepods and krill). The younger prawns (0- to II-group), which are active vertical migrators (Nilssen et al. 1986), only had copepods in their stomachs, while the older ones (especially III- and IV-groups), besides feeding on typically pelagic copepods and krill, also contained some mineral particles and occasional remains of benthic polychaetes. The older, larger prawns appear to spend more time on the bottom than the younger, smaller prawns (Nilssen et al. 1986), and an active or scavenging benthic diet is thus more developed than in younger prawns. Previous studies in Norwegian waters have recorded the presence of copepods, but not krill, in the stomachs of $P$. borealis, but benthic prey, e.g. polychaetes, dominated (Wollebæk 1903, Hjort \& Ruud 1938). North Norwegian fjords such as Balsfjord typically have zooplankton sound-scattering layers (SSLs) comprised mainly of krill with copepods, which descend to the fjord bottom itself at midday (Evans \& Hopkins 1981), thus providing the older, more sedentary prawns with pelagic prey. Wienberg (1981), in one of the most comprehensive studies on the feeding habits of $P$. borealis, points out that prawns caught in bottom trawls in the early morning, after having vertically migrated during the night, are particularly characterized by having zooplankton prey in their stomachs. The presence of capelin scales in the stomachs of Balsfjord prawns is almost certainly the result of discarded capelin in the by-catch of prawn trawlers. Such dead capelin, lying on the fjord bottom, provide ideal scavenging for the older, more sedentary prawns.

The presence of $20: 1(n-9)$ and $22: 1(n-11)$, in highest percentages in lipid in younger Balsfjord prawns, is consistent with the prawns' consuming substantial numbers of calanoid copepods (Falk-Petersen et al. 1987, Sargent \& Falk-Petersen 1988) This conclusion is reinforced by the presence of small amounts of wax esters rich in 20:1 and 22:1 fatty alcohols in the prawns, and agrees well with our stomach contents analysis of the younger animals. It is interesting that the phospholipid of I-group, but not more mature, animals is rich in $20: 1(n-9)$, supporting the conclusion drawn from the triacylglycerol compositions that copepods are important prey items for the young Pandalus borealis. Chemical structural constraints prevent the incorporation of 22:1 into phospholipids, i.e. the absence of this fatty acid from the phospholipids is expected.

As with the arrow worm Sagitta elegans in Balsfjord, the $18: 1(n-7) / 18: 1(n-9)$ ratio of the fatty acids of these
Pandalus borealis is low, pointing to a carnivorousomnivorous diet (Falk-Petersen et al. 1990). However, the presence of saturated fatty alcohols including 22:0, 20:0 and 18:0 (which co-migrates with phytol in the analytical system used) in $P$. borealis possibly indicates the presence of lipids derived from detritus, consistent with the animals' classically cited benthic feeding habit. Nevertheless, short-chain branched fatty acids associated with bottom sediments and sediment-ingesting organisms, such as the asteroid Ctenodiscus crispatus (Falk-Petersen \& Sargent 1982, Sargent et al. 1983), are not prevalent in the lipids of Balsfjord $P$. borealis. Overall, the fatty acid profile of the animals' triacylglycerols is much more consistent with a carnivorous rather than an omnivorous or detritivorous habit.

We have previously argued in earlier analyses of the Balsfjord ecosystem that an elevated level of 18:1 in animal lipid is a crude indicator of a carnivorous diet (Falk-Petersen et al. 1987, 1990). It is known that lipids of the krill Thysanoessa inermis and T. Taschi, and capelin, all of which are abundant in Balsfjord, are rich in 18:1 with the predominantly herbivorous krill species, especially $T$. inermis, containing both $(n-9)$ and $(n-7)$ isomers (Henderson et al. 1984, Falk-Petersen et al. 1987). Therefore, the fatty acid analytical results here are consistent with the intermediate-aged (I- and II-Group) Pandalus borealis moving from a predominantly copepod diet to a predominantly krill diet. possibly supplemented by a diet of discarded capelin (by-catch). This is supported by the stomach analyses.

The data reported here for fatty acid analyses of triacylglycerols and phospholipid are broadly the same as those already reported for total lipid of Pandalus borealis from Canadian and Alaskan waters (Ackman \& Eaton 1967, Krzeczkowski 1970), with the exception that $P$. borealis from these North American waters are moderately richer in 20:1 and 22:1 fatty acids than this species from northern Norwegian fjords. It is possible that wax ester-rich calanoids, almost certainly Calanus sp, are relatively more abundant than euphausiids and capelin in the diet of more mature $P$. borealis from North American waters. If so, this is likely to be a direct reflection of the relative abundance of calanoids and krill in these environments

The triacylglycerols of Pandalus borealis and its eggs contain modest quantities of $(n-3)$ polyunsaturated fatty acids with the percentage of $20.5(n-3)$ exceeding that of $22: 6(n-3)$. The phospholipids, as expected, contain larger percentages of $(n-3)$ polyunsaturates than the triacylglycerols with the percentage of $20: 5(n-3)$ again being greater than that of $22: 6(n-3)$. These findings establish the high nutritional value of the animal's lipirt for marine predators including man, and conform. to the general pattern for marine invertebrate lipid (Sargent 1976, Sargent \& Whittle 1981, Clarke 1983). 


\section{Seasonality and growth}

Storage of lipid in Balsfjord Pandalus borealis occurs when the biomass and population density of their copepod and krill prey is high and these prey are in peak condition (i.e. the prey are lipid-rich). The decline in growth rate of $P$. borealis in winter coincides with the cessation of feeding and declining condition of their primarily herbivorous prey (Hopkins et al. 1984b, 1989a) Our findings thus emphasise that $P$. borealis in Balsfjord preys primarily on pelagic organisms. The seasonal production cycle, both in terms of quantity and quality, strongly influences the deposition and mobilization of the prawns' lipid reserves.

Acknowledgements. We thank university technicians Laina Dalsbø, Astrid Hermannsen and Britt Vaaja for analytical assistance, and skipper Kare Bendiksen of RV 'Ottar' for his help and enthusiasm at sea. We are grateful for the support of the Norwegian Fisheries Research Council (NFFR, Project nos. 1.401.025 \& 1.500.003), and the UK Natural Environment Research Council (NERC). This work comprises part of the 'Balsfjord Project' of the University of Tromsø.

\section{LITERATURE CITED}

Ackman, R. G., Eaton, C. A. (1967). Fatty acid composition of the decapod shrimp, Pandalus borealis, in relation to that of the euphausiid, Meganyctiphanes norvegica. J. Fish Res. Bd Can. 24: 467-471

Båmstedt, U. (1974). Biochemical studies of the deep-water pelagic community of Korsfjorden, western Norway. Methodology and sample design. Sarsia 56: 71-86

Cassie, R. M. (1954). Some uses of probability paper in the analysus of size frequency distributions. Aust. J. mar Freshwat. Res. 5(3): 515-522

Clarke, A. (1977a). Seasonal variations in the total lipid content of Chorismus antarcticus (Pfeffer) iCrustacea: Decapoda) at South Georgia. J. exp. mar. Biol. Ecol. 27: 93-106

Clarke, A. (1977b). Lipid class and fatty acid composition of Chorismus antarcticus (Pfeffer) (Crustacea: Decapoda) at South Georgia. J. exp. mar. Biol. Ecol. 28: 297-314

Clarke, A. (1979). Lipid content and composition of the pink shrimp. Pandalus montagui (Leach) (Crustacea: Decapodaj. J. exp. mar. Biol. Ecol. 38: 1-17

Clarke, A. (1982). Lipid synthesis and reproduction in the polar shrimp Chorismus antarcticus. Mar. Ecol. Prog. Ser. 9: $81-90$

Clarke, A. (1983). Life in cold water: the physiological ecology of polar marine ectotherms. Oceanogr. mar Biol. A. Rev. 21: $341-453$

Clarke, A. (1987). Temperature, latitude and reproductive effort. Mar. Ecol. Prog. Ser. 38: 89-99

Clarke, A., Peck, L. S. (1991). The physiology of polar marine zooplankton. In: Sakshaug, E., Hopkins, C. C. E., Øritsland, N. A. (eds.) Proceedings of the Pro Mare Symposium on Polar Marine Ecology. Polar Res. 10(2): 355-369

Cleveland, W. S. (1979). Robust locally weighted regression and smoothing scatterplots. J. Am. Stat. Ass. 74: 829-836

Cushing, D. H. (1975). Marine ecology and fisheries. Cambridge University Press, Cambridge

Cushing, D. H. (1981). Fisheries biology, a study in population dynamics. University of Wisconsin Press, Madison
Eilertsen, H. C., Taasen, J. P. (1984). Investigations on the plankton community of Balsfjorden, northern Norway: the phytoplankton 1976-1978, environmental factors, dynamics of growth, and primary production. Sarsia 69: $1-15$

Evans, R. A., Hopkins, C. C. E. (1981). Distribution and standing stock of zooplankton sound-scattering layers along the north Norwegian coast in February--March, 1978. Sarsia 66: $147-160$

Falk-Petersen, 1.-B., Sargent, J. R. (1982). Reproduction of asteroids from Balsfjorden, northern Norway: analyses of lipids in the gonads of Ctenodıscus crispatus. Asterias lincki and Pterdster milhtaris. Mar. Biol. 69: 291-298

Falk-Petersen, S. (1981). Ecological investigations on the zooplankton community of Balsfjorden, northern Norway: seasonal changes in body weight and the main biochemical composition of Thysanoessa inermis (Kroyer), T. raschii (M. Sars), and Meganyctiphanes norvegica (M. Sars) in relation to environmental factors. J. exp. mar. Biol. Ecol. 49: $103-120$

Falk-Petersen, S., Gatten, R. R., Sargent, J. R., Hopkins, C. C. E. (1981). Ecological investigations on the zooplankton community of Balsfjorden, northern Norway: seasonal changes in the lipid class composition of Meganyctiphanes norvegica (M. Sars), Thysanoessa raschii (M. Sars) and T. inermis (Kroyer). J. exp. mar. Biol. Ecol. 54: $209-224$

Falk-Petersen, S., Hopkins, C. C. E., Sargent, J. R. (1990), Trophic relationships in the pelagic, Arctic food web. In: Barnes, M., Gibson, R. N. (eds.) Trophic relationships in the marine environment. Proc. 24th Eur. Mar. Biol. Symp., p. $315-333$

Falk-Petersen, S., Sargent, J. R, Tande, K. S. (1987). Lipid composition of zooplankton in relation to the subarctic food web. Polar Biol. 8: 115-120

Farquhar, J. W (1962). Identification and gas-liquid chromatographic behaviour of plasmalogen aldehydes and their acetal alcohol and acetylated alcohol derivates. J. Lipid Res. 3: 21-30

Fewster, M. E., Burns, B. J., Mead, J F. (1969). Quantitative densitometric thin-layer chromatography of lipids using copper acetate reagent. J. Chromatogr. 43: 120-126

Folch, J., Lees, M., Sloane Stanley, G. H. (1957). A simple method for the solation and purification of total lipids from animal tissues. J. biol. Chem. 226: 497-509

Fréchette, J., Parsons, D. G. (1983). Report of shrimp ageing workshop held at Ste. Foy, Quebec, in May and at Dartmouth, Nova Scotia, in November 1981. N. Atlant. Fish. Org. scient. Coun. Stud. 6: 79-100

Gornall, A. G., Bardawill, C. J., David, M. M. (1949). Determination of serum proteins by means of the biuret reaction. J. biol. Chem. 177: 751-766

Gayanilo, F. C., Soriano, M., Pauly, D. (1988). A draft guide to the compleat ELEFAN. ICLARM Software 2, Manila

Harding, I. P. (1949). The use of probability paper for the graphical analysis of polymodal frequency distributions. J. mar. biol. Ass. U.K. 28: 141-153

Henderson, R. J., Sargent, J. R., Hopkins, C. C. E. (1984). Changes in the content and fatty acid composition of lipid in an isolated population of the capelin Mallotus villosus during sexual maturation and spawning. Mar Biol. 78 : 255-263

Hill, M. O. (1982). Correspondence analysis. In: Kotz-Johnson, S. (ed.) Encyclopedia of statistical sciences, Vol. 2. John Wiley, New York, p. 204-210

Hjort, J., Ruud, J. T (1938). Deep-sea prawn fisheries and their problems. Hvalråd. Skr. 17: 1-144 
Hopkins, C. C. E. (1979). Ecobiochemical studies on Pandalus borealis (Krøyer) from Balsfjord, northern Norway: preliminary results from a winter situation. Comm. Meet. int. Coun. Explor. Sea C.M.-ICES/K: 31 (mimeo)

Hopkins, C. C. E., Grotnes, P. E., Eliassen, J.-E. (1989a). Orqanization of a fjord community at $70^{\circ}$ North: the pelagic food web in Balsfjord, northern Norway. Rapp. P.-v. Réun. Cons. int. Explor. Mer 188: 146-153

Hopkins, C. C. E., Nilssen, E. M. (1990). Population biology of the deep-water prawn (Pandalus borealis) in Balsfjord, northern Norway. 1. Abundance, mortality, and growth, 1979-1983. J. Cons. int. Explor. Mer 47: 148-166

Hopkins, C. C. E., Nilssen, E. M., Hermannsen, A., Vaaja, B. Dalsbo, L. (1989b). Body composition and energetic predictors of age/season in the prawn Pandalus borealis Comm. Meet. int. Coun. Explor. Sea C.M.-ICES/K: 10 (mimeo)

Hopkins, C. C. E., Nyholmen, O., Solheim, L. (1986) Qualitative and quantitative models relating otolith zone deposition to growth and condition in sexually mature male and female capelin (Mallotus villosus). Polar. Biol. 6: 25-36

Hopkins, C. C. E., Seiring, J. V., Nyholmen, O., Hermannsen, A. (1984a). Ecological energetics from total lipid and total protein: fact and artefact using a gravimetric method for lipid and a biuret method for protein. Oceanogr. mar. Biol. A. Rev. 22: 211-261

Hopkins, C. C. E., Tande, K. S., Gronvik, S., Sargent, J. R. (1984b). Ecological investigations of the zooplankton community of Balsfjorden, northern Norway: an analysis of growth and overwintering tactics in relation to niche and environment in Metridia longa (Lubbock), Calanus finmarchicus (Gunnerus). Thysanoessa inermis (Kroyer) and Thysanoessa raschi (M. Sars). J. exp. mar. Biol. Ecol. 82: $77-99$

Hopkins, C. C. E., Tande, K. S., Gronvik, S., Sargent, J. R., Schweder, T. (1985). Ecological investigations of the zooplankton community of Balsfjorden, northern Norway. Growth. and quantification of condition, in relation to overwmtering and food supply in Metridia longa, Calanus finmarchicus, Thysanoessa inermis and Thysanoessa raschi. In: Gray, J. S., Christensen, M. E. (eds.) Marine biology of polar regions and effects of stress on marine organisms. John Wiley, Chichester, p. 83-101

Krzeczkowski, R. A. (1970). Fatty acids in raw and processed Alaska pink shrimp. J. Am. Oll Chem. Soc. 47: 451-453

Lee, R. F. (1975). Lipids in arctic zooplankton. Comp Biochem. Physiol. 51B: 263-266

Lee, R. F., Hirota, J. (1973). Wax esters in tropical zooplankton and nekton and geographical distribution of wax esters in marine copepods. Limnol. Oceanogr. 18: 227-239

Love, R. M. (1970). The chemical biology of fishes. Academic Press, London

Lutter, S., Taasen, J. P., Hopkins, C. C. E., Smetacek, V (1989). Phytoplankton dynamıcs and sedimentation processes during spring and summer in Balsfjord, northern Norway. Polar Biol. 10: 113-124

Nilssen, E. M., Larsen, R. B., Hopkins, C. C. E. (1986). Catch and size selection of Pandalus borealus in a bottom trawl and implications for population dynamics analyses. Comm. Meet. int. Coun. Explor Sea C.M.-ICES/K: 4 (mimeo)

Norrbin, F., Båmstedt, U. (1984). Energy contents in benthic and planktonic invertebrates of Kosterfjorden, Sweden. Ophelia 23: 47-64

Ouellet, P., Taggert, C. T., Frank, K. T (1992). Lipid condition and survival in shrimp Pandalus borealss larvae. Can. J. Fish. Aquat. Sci. 49(2) $368-378$
Pauly, D (1984). Fish population dynamics in tropical waters a manual for use with programmable calculators. ICLARM Studies and Reviews 8, ICLARM, Manila

Pauly, D., Gaschütz, G. (1979). A simple method for fitting oscillatıng length growth data, with a program for pocket calculators. Comm. Meet. int. Coun. Explor. Sea C.M. ICES/G: 24 (mimeo)

Phillipson, J. (1964). A miniature bomb calorimeter for small biological samples. Oikos 15: 130-139

Rasmussen, B. (1953). On the geographical variation in growth and sexual development of the deep sea prawn (Pandalus borealis KR). Fisk. Dir. Skr. (Ser. Havunders.) 10(3)

Ricker, W. (1975). Computations and interpretation of biological statistics of fish populations. Bull. Fish. Res. Bd Can. 191

Rohlf, F. J. (1989). NTSYS-pc. Numerical taxonomy and multivanate analysis system. Version 1.50. Exeter Publishing Ltd, New York

Sargent, J. R. (1976). The structure, metabolism and function of lipids in marine organisms. Biochem. biophys. Perspect. mar. Biol. 3: 149-212

Sargent, J. R., Falk-Petersen, S. (1981). Ecological investigations on the zooplankton community in Balsfjorden, northern Norway: lipids and fatty acids in Meganyctiphanes norvegica, Thysanoessa raschi and T. inemis mid-winter. Mar. Biol. 62: 131-137

Sargent, J. R., Falk-Petersen, S. (1988). The lipid biochemistry of calanoid copepods. Hydrobiologia 167/168: 101-114

Sargent, J. R., Henderson, R. J (1986). Lipids. In: Corner, E. D. S. (ed.) The biological chemistry of calanoid copepods. Clarendon Press, Oxford, p. 59-108

Sargent, J. R., Hopkins, C. C. E., Seiring, J. V., Youngson, A. (1983). Partial characterization of organic material in surface sediments from Balsfjorden, northern Norway, in relation to its origin and nutritional value for sedimentingesting animals. Mar. Biol. 76: 87-94

Sargent, J. R., Whittle, K. (1981). Lipids and hydrocarbons in the marine food web. In: Longhurst A. R. (ed.) Analysis of marine ecosystems. Academic Press, London, p. 491-533

Seiring, J. V., Hopkins, C. C. E. (1985). Analyses of starvationstress on respiration rates, and body weight and composition in the deep-water prawn Pandalus borealis from Balsfjorden, northern Norway, measured during mid-summer in a laboratory experiment. In: Gray, J. S., Christiansen, M. E. (eds.) The marine biology of polar regions and effects of stress on marine organisms. John Wiley, Chichester, p. 287-298

Shumway, S., Perkins, H. E., Schick, D. F., Stickney, A. P. (1985). Synopsis of biological data on the pink shrimp, Pandalus borealis Krøyer, 1838. NOAA Technical Report NMFS 30 (FA.O Fisheries Synopsis No. 144)

Vernberg, F. J. (1987). Crustacea. In: Pandian, T. J., Vernberg, F. J. (eds.) Animal energetics, Vol. 2, Protozoa through Insecta. Academic Press, San Diego, p. 301-372

von Bertalanffy, L. (1938). A quantitative theory of organic growth. Hum. Biol. 10(2): 181-213

Wienberg, R. (1981). On the food and feeding habits of Pan. dalus borealis Kroyer. Arch. FischWiss. 31(3): 123-137

Wilkinson, L. (1988a). SYSTAT: the system for statistics. Systat, Inc., Evanston, IL

Wilkinson, L. (1.988b). SYGRAPH: the system for graphics. Systat, Inc., Evanston, IL

Wollebæk, A. (1903). Ræker og rækefiske. Årsberetn. Norg. Fisk. 1903: 167-229

Zar, J. H. (1974). Biostatistical analysis. Prentice-Hall, Englewood Clifts 